\title{
The Efficiency of Selected Banking Sectors in the European Union
}

\author{
Liběna Černohorská \\ University of Pardubice \\ Faculty of Economics and Administration, Institute of Economic Sciences \\ Studentská 95, 53210 Pardubice, Czech Republic \\ E-mail: libena.cernohorska@upce.cz
}

\begin{abstract}
When measuring bank efficiency, there is no generally accepted concept of efficiency nor is there a uniform system of indicators for its measurement. It is, however, possible to use the method of financial analysis to measure bank efficiency. In this paper, the following ratios are used for measuring bank efficiency: ROA, ROE, total assets, nonperforming loans/total loans, quick liquid assets/total assets, quick liquid assets/short-term liabilities, loans/deposits, and capital adequacy. The goal of this paper is to assess the efficiency of Czech banks using cluster analysis on the basis of selected ratios and to conduct a comparison with bank efficiency in Poland, Austria, Greece, Portugal, France, and Slovakia. The collective ratios for the entire banking sector will be compared for the selected countries for the years 2010-2013. Cluster analysis demonstrates that the Czech banking sector is the most similar to the Slovakian sector. According to a combination of selected ratios, it is possible to designate the cluster composed of the Czech and Slovak banking sectors as being the cluster with the highest banking sector efficiency. It differs extensively from the cluster of Greece and Portugal.
\end{abstract}

Keywords: bank, banking sector, banks efficiency, cluster analysis, principal component analysis

JEL codes: G14, G21, C38

\section{Introduction}

A functional banking market is an integral and vital part of every market economy. Like other industries, the banking industry has its own unique characteristics and specifics that adapt to internal and external influences of the economic sector. Each state requires a reliable and stable banking system for the economy to function properly, because problems in the banking sector may have an impact on the entire financial sector. Each country's banking system has its own specifics that influence universal globalization. The system is based on banking systems around the world. Each country accepts various elements in different ways. Certain states retain more of their traditional banking features, which arose during the system's development; others however, adopt various elements of the globalized economy (Černohorský and Prokop, 2016).

Banks are an inseparable part of life for all economic subjects (Hedvičáková and Svobodová, 2015). Bank stability and efficiency is an important prerequisite for the financial markets' operation (Serdarevic and Teplý, 2011; Černohorský, 2014). For qualified analysis, it is necessary to work with a time 
series of ratios and monitor the trends of their development over previous periods of time (Tokarčíková et. al., 2014; Svobodová, 2013). The aim of this article is to conduct a cluster analysis for the efficiency of selected banking sectors in the following European Union countries: Slovakia, Poland, Austria, the Czech Republic, France, Portugal, and Greece. The selected countries are European Union countries that have financial markets and banking sectors at different levels of development. Economic transformation has deeply affected the structure, nature, and role of the banking sector across the entire national economy. Currently, the banking sectors in the Czech Republic, Poland, and Slovakia have a stable ownership structure. The majority share of the domestic banking sector's overall registered capital consists of long-term foreign capital with a direct share. Czech, Polish, and Slovak banks are characterized by unprecedented stability and have shown many billions in profit even during the period of the global financial and economic crisis (Vodová, 2013). Cluster analysis results in creating clusters of individual banking sectors exhibiting similar values for the selected criteria.

The banking system in the European Union is unique in that there is a European Central Bank plus national central banks and commercial banks in individual countries. There are two types of banking systems in individual European Union (EU) countries, universal or two-tiered. Harmonized legal standards governing banking apply to them, and the same conditions exist for providing commercial banks with banking licenses. The Eurosystem is comprised of the ECB as well as all the national central banks that have accepted the euro. These countries have conceded jurisdiction on national monetary policy, which they have handed over to the ECB, which implements the given monetary policy in the given economic space. This grouping of central banks shapes and implements the Eurozone's monetary policy through their representatives. The countries that are part of the EU but have not accepted the euro implement their own monetary policy. Together with the $E C B$, their central banks comprise the European central banking system. The Czech Republic and Poland are examples of such countries.

The creators of the European Monetary Union believe that member economies will begin to converge after the introduction of a common currency. However, the Eurozone is quite heterogeneous and diverse as a monetary union because of the dissimilarity of the individual member countries. A single monetary policy for all countries will not satisfy all the member countries. Moreover, a uniform interest rate encourages peripheral economies to overheat and slower growth for more advanced countries. In addition to the global financial crisis, it is also possible to record the impact of a so-called debt crisis. This is the situation where countries begin to fall into bankruptcy in the wake of their inability to pay the debt they have gradually accumulated. The term PIIGS has been widely used for these countries - it is an acronym of the first letters of the English names off the indebted countries (Portugal, Italy, Ireland, Greece, and Spain).

The goal of this paper is to assess the efficiency of Czech banks using cluster analysis on the basis of selected ratios and to conduct a comparison with bank efficiency in Poland, Austria, Greece, Portugal, France, and Slovakia. There will 
be a comparison of the stable banking sectors (the Czech, Polish, Austrian, and French banking sectors) and the banking sectors that were affected by financial crises (the Portuguese and Greek banking sectors).

The paper continues as follows: in Section 1, the author presents a review of the literature on bank efficiency. In Section 2, cluster analysis is conducted. In Section 3, an evaluation of banking sector performance is conducted for the chosen countries using the selected ratios. In Section 4, data visualization is presented using factor analysis and cluster analysis. In last section, the author presents conclusions and final remarks.

\section{Literature Review}

Based on current research in the literature on bank efficiency, it is evident that there is a wide range of views on evaluating bank efficiency and that measuring efficiency is therefore very difficult. There are numerous methods for measuring efficiency; the fundamental question is which indicators to use to measure this efficiency.

Efficiency is often understood in the same sense as performance and profitability (as in Atemnkeng and Nzongang, 2006 or Molyneux and Thornton, 1992). When banks are run efficiently, the operational costs are reduced, leading to an increase in the profits realized by the banks. The authors Richard, Devinney, et al. (2009) conducted an analysis of more than 213 articles in leading international journals that use particular indicators based on accounting data to measure efficiency; these indicators mainly include cash flow, financial results, revenues and their growth, and asset profitability indicators.

Profitability was used to measure bank efficiency by Altunbas (1998); Bonin et al. (2005); Abbasoglu, Aysan, and Günes (2007); and Berger et al. (1993), for example. These authors evaluate bank profitability using return on assets (ROA) or return on equity (ROE). Bonin et al. (2005) also monitored the amount of total deposits, total assets, loans, and liquid assets. The size of a bank is judged by its total assets (Dabla-Norris \& Floerkemeier 2007; Fuentes \& Vergara, 2003). Berger et al. (1993) also use the indicators of total assets, loans, and total loans/total deposits to assess bank efficiency in addition to ROE and ROA. Groenveled and de Vries (2009) use the capital ratio for measuring bank efficiency. Bank efficiency is frequently evaluated using bank ownership structure (Fuentes \& Vergara, 2003; Bonin et al., 2005; Mester, 1993). Some authors take into account the cost of labor when measuring bank efficiency (Stavárek \& Řepková 2013; Tulekns, 2006; Berger et al., 1993) and the cost of capital (Berger et al., 1993). Another factor influencing bank efficiency is interest margin (Stavárek \& Repková, 2013; or Dabla-Norris \& Floerkemeier, 2007). These last authors also use the indicator of rapidly nonperforming loans/total loans, liquid assets/total assets, and quick liquid assets/short-term liabilities.

\section{Methodology and Data}

Evaluating bank efficiency is a relatively complicated analytical problem. There is no generally accepted concept of efficiency nor is there a uniform system of indicators for measuring bank efficiency. It is, however, possible to use the method of financial analysis to measure bank efficiency. The goal of financial 
analysis is to evaluate the financial ratios for efficiency and competitiveness that were achieved in prior periods of time. In this paper, the following ratios are used for measuring bank efficiency: ROA, ROE, total assets, nonperforming loans/total loans, quick liquid assets/total assets, quick liquid assets/shortterm liabilities, loans/deposits, and capital adequacy. The collective ratios for the entire banking sector are compared for the selected countries for the years 2010-2014. The necessary data were obtained from the Bankscope database and were chosen with regard to the specifics of the selected banking sectors, international accounting standards, and banks' information requirements. A comparison was made of the average values of the selected indicators in individual banking sectors. In further scientific study, it would be possible to use a longer time series for the selected indicators of these banking sectors for a more detailed analysis. It would be possible to monitor factors that affect the efficiency of banking sectors (such as the period before the financial crisis and the impact of the financial crisis on selected criteria) and to subsequently track the clusters created, etc.

Peer analysis makes it possible to conduct a comparison of the financial variables using tables and graphs. For this peer analysis, the traditional methods of multiple statistical analysis - especially cluster analysis and principal components analysis - were used. The method of cluster analysis was used to compare the efficiency of the Czech banking sector with the banking sectors of the other selected European countries. Cluster analysis divides the selected countries into clusters according to similarity. Using the method of principal component analysis, it was determined that there are two main components that jointly explain nearly three-quarters of the variability.

\subsection{Cluster Analysis}

The primary method for determining the similarity of quantitative variables is factor analysis. This is based on principal component analysis, which is used to reduce the size of the task (instead of determining many variables for further calculations, only a small number of principal components are determined these can be expressed as linear combinations of the original variables).

Principal component analysis is computed by the singular value decomposition of X. (Friedman et al., 2013). The general formula (1) is:

$$
X=U D W^{T}
$$

where $D$ is a diagonal matrix consisting of the set of all eigenvalues of $C$ along its principal diagonal and 0 for all other elements; $U$ is an $n-b y-n$ matrix, the columns of which are orthogonal unit vectors of the length $n$, called the left singular vectors of $X ; W$ is a $\mathrm{p}$-by-p matrix whose columns are orthogonal unit vectors of the length $p$, called the right singular vectors of $X$.

In principal component analysis (PCA), the data are summarized as a linear combination of an orthonormal set of vectors. The first principal component accounts for as much of the variability in the data as possible, and each successive component represents as much of the remaining variability as possible (Zou et al., 2006). Components accounting for maximal variance are 
retained while other components accounting for a trivial amount of variance are not retained. These techniques are typically used to analyze groups of correlated variables representing one or more common domains. The result of PCA enters into the factor analysis. Its aim is to assess the structure and relationships of the selected indicators to see if they can be divided into groups in which the indicators from the same groups are more closely related than correlated variables from different groups.

Cluster analysis is a collective term covering a wide variety of techniques for delineating natural groups or clusters in data sets. This paper uses hierarchical agglomerative clustering.

Hierarchical agglomerative clustering starts at the bottom and recursively merges a selected pair of clusters into single clusters at each level. This produces a grouping at the next higher level with one less cluster. The algorithm of hierarchical agglomerative clustering begins with every observation representing a singleton cluster. At each of the $\mathrm{N}-1$ steps, the closest two (least dissimilar) clusters are merged into a single cluster, producing one less cluster at the next higher level (Friedman et al., 2001).

In the first phase, clustering calculates the relative distances of objects and transcribes them into a matrix. This leads to a square symmetric matrix $\mathbf{D}=\{d(R, S)\}$, which has zeros on the main diagonal. The Euclidean method is the metric distance matrix that is normally used for calculation. It is based on the geometric model (Klímek, 2005). The objects characterized by $p$ characters are assigned to the points in p-dimensional Euclidean space Ep, i.e., two dots $(R, S)$. This is defined by Euclidean distance as described by the general formula (2):

$$
d(R, S)=\sqrt{\sum_{i=1}^{p}\left(x_{r i}-x_{s i}\right)^{2}}
$$

On the basis of the distance matrix, the second phase calculations (also clustering) can be initiated. The farthest neighbor clustering method was used (also called complete-linkage clustering). Complete-linkage agglomerative clustering takes the intergroup dissimilarity to be that of the farthest (most dissimilar) pair according to formula (3):

$$
d(R, S)=\max _{\substack{O \in R \\ O \in S}}\left\{d\left(O_{i}, O_{j}\right)\right\} \text { for } R \neq S,
$$

where $R, S$ represent two such groups; $d(R, S)$ represents the dissimilarity between $\mathrm{R}$ and $\mathrm{S}$ as computed from the set of pairwise observation dissimilarities $d\left(O_{i}, O_{j}\right)$, where one member of the pair, $O_{i}$, is in $\mathrm{R}$, and the other, $O_{j}$, is in $\mathrm{S}$. 
The clustering methods were selected based on the degree of credibility and the cophenetic correlation coefficient, "CC". The higher the value of the correlation coefficient cophenetic (a value close to 1), the greater the credibility and the better the choice for a suitable model cluster. (Friedman et al., 2001; Romesburg, 2004).

The result is a diagram called a dendrogram, which provides a complete description of the hierarchical agglomerative clustering that is easy to interpret.

\section{Comparison of Banking Sector Performance Using the Selected Ratios}

According to Polouček (2006), evaluating bank performance is important for various interest groups. For shareholders, it influences not only the value of their assets via a specified price for bank shares but also the dividends paid out. Manager evaluations are often derived from economic results. Economic results are also an important issue that is monitored by the central bank as a regulatory and supervisory body in order to preserve the stability of the banking sector. Not least, a bank's performance is also important for clients, whom it can assist when selecting the most suitable institution for their intended financial activities. It is evident that the impact of bank performance is far-reaching and discernible not only for individuals and the banking sector but also consequently for the business sector and the national economy as a whole. This is also why bank management must be constantly and very carefully monitored and evaluated. Next, performance analysis primarily serves as a foundation for managerial decision making and, at the same time, it is frequently used by banking's regulatory and supervisory body for adopting adequate measures that attempt to preserve the stability of the banking sector. There are numerous ratios that express a great deal about bank performance itself; these are calculated and evaluated for the internal needs of banks and the needs of bank regulation and supervision. In this section, evaluation of banking sector performance has been conducted for the chosen countries using the selected ratios for 2010-2013.

As to the percentage of nonperforming loans, it is clear from Fig. 1 that the greatest percentage of loans to assets is held by Greece, whose banking sector performance is strongly disrupted by this high percentage of nonperforming loans. Portugal follows after Greece, although there is a distinct lag between them. Austria's results for this ratio are the best; during the period being examined, they show a value of around $3 \%$. The other countries fall in a similar range, and their share of nonperforming loans is stable, around $5 \%$.

The percentage of easily liquid assets to total assets is depicted in Fig. 2 . The best results of the selected countries for this ratio were shown by France, Slovakia, and the Czech Republic, with values fluctuating around 35\%. Even Greece showed surprisingly good results. The worst results for this ratio were recorded by Portugal. In 2013, Portugal possessed too many easily liquidated instruments in its asset structure at the expense of less liquid ones, which tend to be more profitable. 
Figure 1 Nonperforming loans in the selected countries for 2010-2013 (in \%)

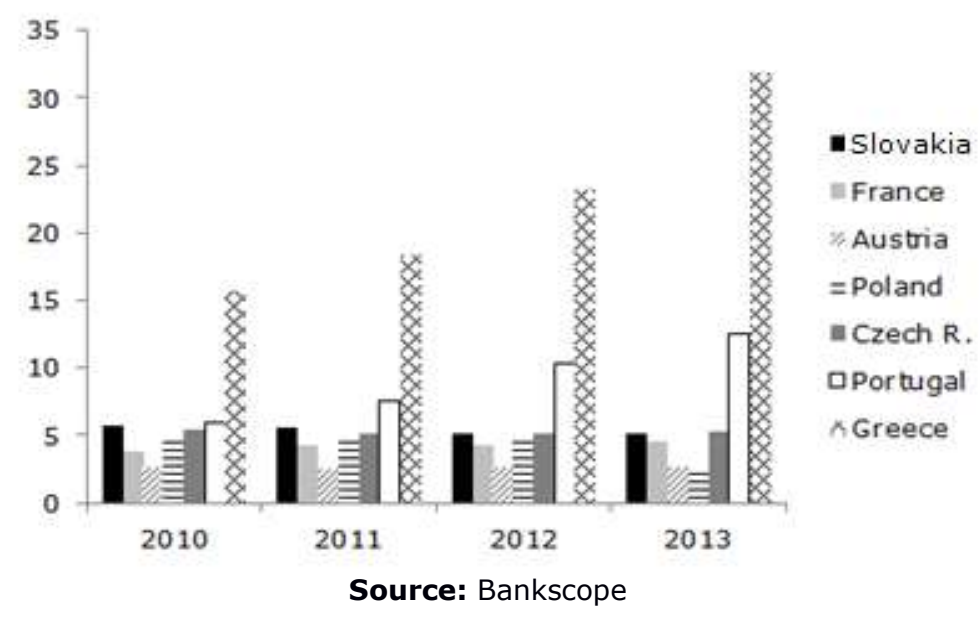

Figure 2 Liquid assets to total assets in the selected countries for 2010-2013 (in \%)

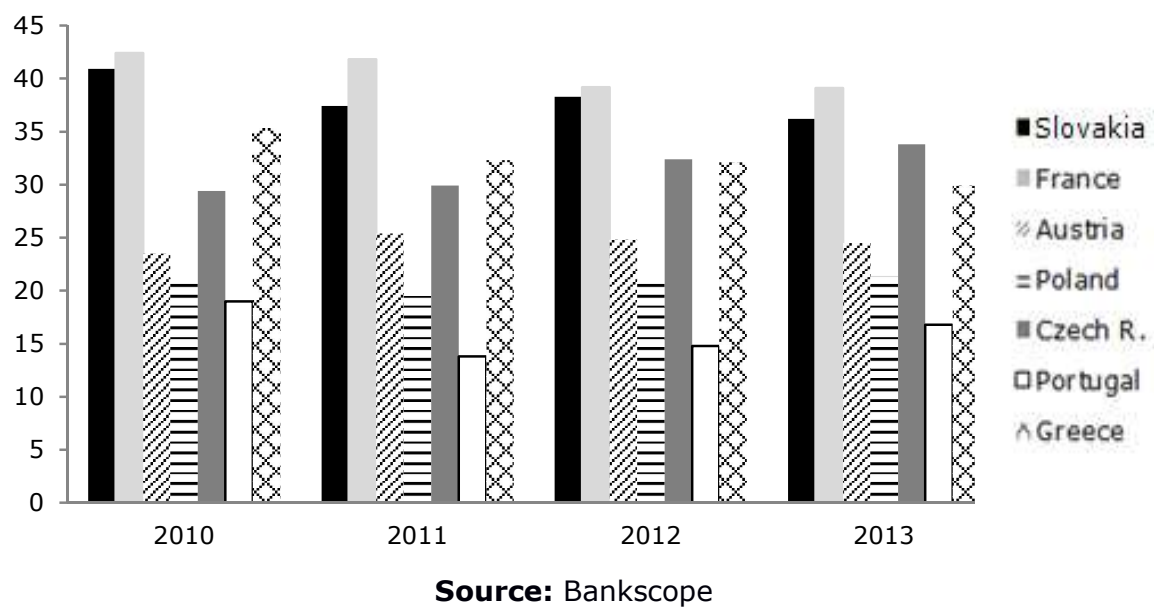

For capital adequacy, all the countries examined exceed the set minimum limit of $8 \%$, which is clear from Fig. 3. The highest values were shown for this ratio over the long term by Slovakia, the Czech Republic, and Austria. The lowest values were shown by Portugal and Greece, which dipped just beyond the minimum set limit in 2012. In the last year examined, however, both countries also achieved the $8 \%$ set limit for capital adequacy. 
Figure 3 Capital adequacy in the selected countries for 2010-2013

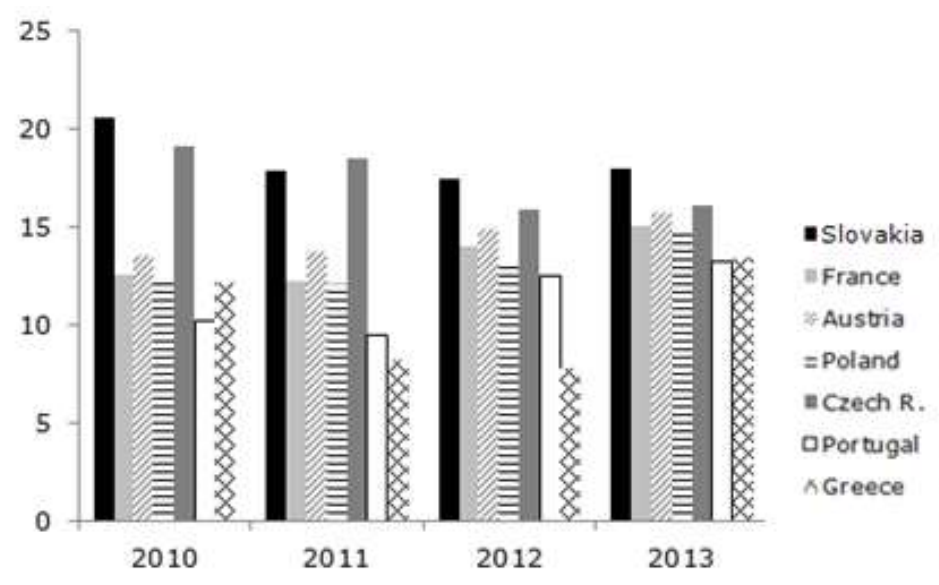

Source: Bankscope

Although Greece showed good return on assets in 2013, it is clear from Fig. 4 that it had significant problems with this ratio in the immediately preceding years, because its value ranged deep into the negative numbers. Negative results were also recorded for the other problem country, Portugal. Austria also had a very low return on assets, and not even France reached the optimum ROA value of $1 \%$. It can be said that the remaining countries showed standard values for their return on assets.

Figure 4 Return on assets in the selected countries for 2010-2013 (in \%)

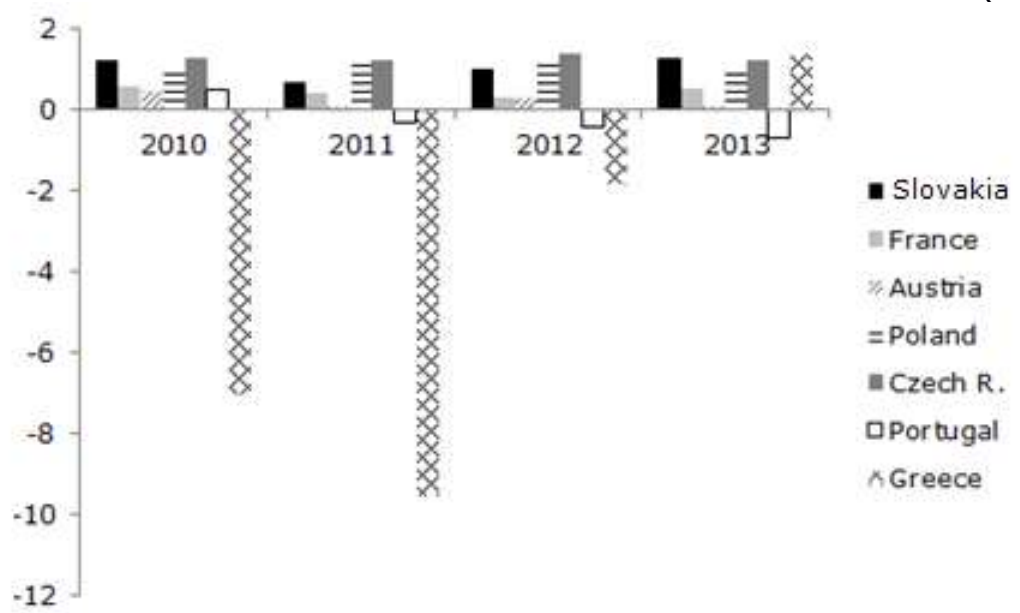

Source: Bankscope

The highest values for return on equity were achieved by the Czech Republic and Poland. On the other hand, it is clear at first glance from Fig. 5 that Greece showed distinctly negative values exceeding $100 \%$. Portugal also 
ranged in the negative values for return on equity. Again, Austria also recorded low values.

Figure 5 Return on equity in the selected countries for 2010-2013 (in \%)

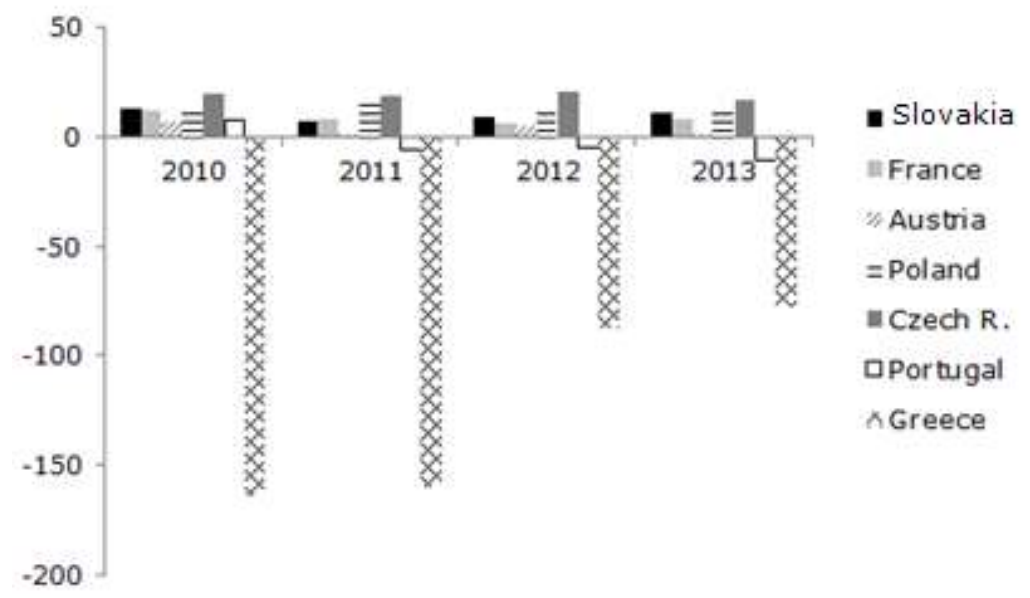

Source: Bankscope

On the basis of the above, it is clear that the Czech and Slovak banking sectors have achieved excellent performance in comparison with other European countries. On the other hand, the banking sectors of Greece and Portugal have been faring the worst. Cluster analysis is conducted next to determine similarities in banking sector performance.

\section{Results and Discussion}

The basic prerequisite for performing cluster analysis is to prove that the data are not affected by multicollinearity. Multicollinearity could very significantly affect the final quality of the clustering and the classification of the individual elements in the resulting clusters. It is necessary to establish the correlation matrix. Next, caused to that show must be eliminated afor is kept, itis necessary to provide a justification for its further presence in the cluster analysis. For more information, see Friedman et al. (2001).

Based on the results of the correlation matrix, the ratio of nonperforming loans/total loans was removed from the analysis. This indicator showed very high levels of correlation with ROE as well as with the proportion of quick liquid assets/short-term liabilities, which is highly correlated with ROA.

To obtain information on the impact of these indicators, the principal component method was applied, followed by factor analysis. Both methods are used for data visualization and obtaining input information.

\subsection{Data Visualization Using Factor Analysis}

The principal component method determined that there are two main components which together explain nearly three-quarters of the variability (Table 1). 
The first principal component depletes approximately $47.96 \%$ of the total variability in the data, the second approximately $25.81 \%$. The results of factor analysis are shown in Table 1 and Fig. 1. Table 1 shows which criteria are important for further exploration in terms of classification into certain objects, respectively clusters (boldface type).

Table 1 The result of the factor analysis

\begin{tabular}{lcc}
\hline & $\begin{array}{c}\text { First Principal } \\
\text { Component 1 }\end{array}$ & $\begin{array}{c}\text { Second Principal } \\
\text { Component 2 }\end{array}$ \\
\hline Total assets & 0.39 & $\mathbf{0 . 8 0}$ \\
\hline Liquid assets/Total assets & $\mathbf{0 . 7 7}$ & 0.26 \\
\hline Loans/Deposits & 0.60 & 0.04 \\
\hline Capital adequacy & 0.62 & 0.64 \\
\hline ROA & $\mathbf{0 . 9 1}$ & -0.12 \\
\hline ROE & -0.19 & $\mathbf{0 . 9 7}$ \\
\hline
\end{tabular}

Source: Author's own work

Graphic representation of the data visualization from the factor analysis assumes the possible creation of approximately four relevant clusters (Figure $6)$.

Figure 6 Factor analysis - the number of clusters

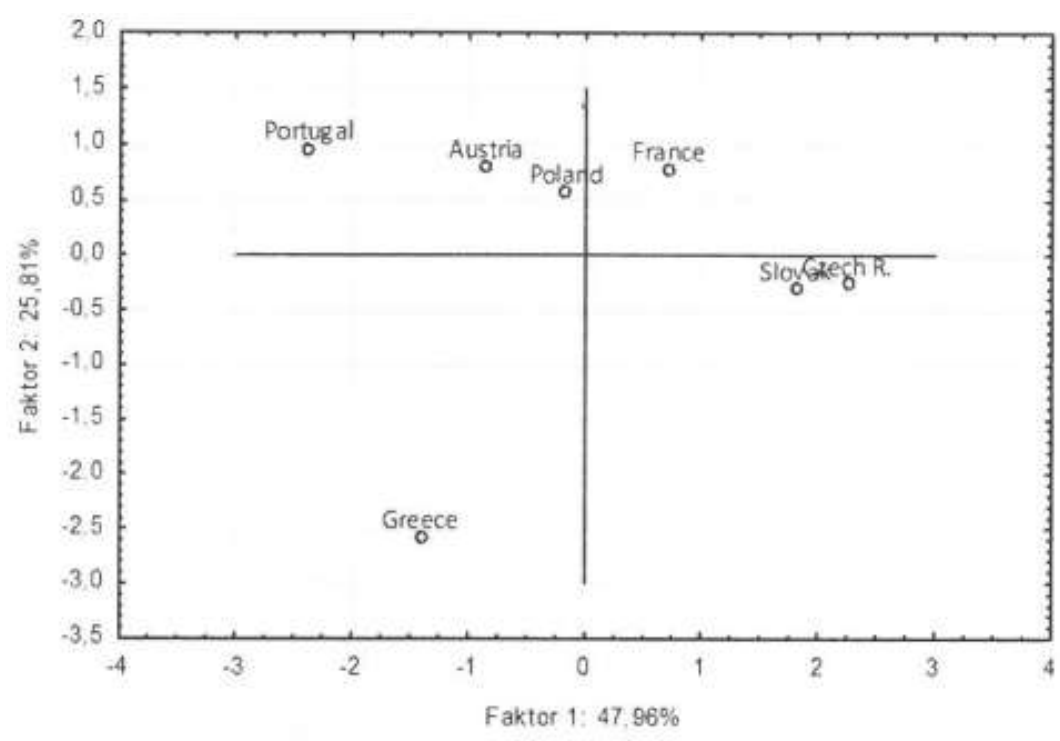

Source: Author's own work

\subsection{The Results of Cluster Analysis}

Cluster analysis was used to compare the selected banking sectors. This analysis divides the selected countries into clusters according to their similarities. To perform cluster analysis, we have assumed agglomerative hierarchical clustering. For more information, see Romesburg (2004). Next followed the selection of clustering procedures, namely a clustering method 
(the farthest neighbor method, i.e., complete-linkage clustering, using statistical software) and the distance calculation method (Euclidean distance). The clustering method was selected based on the degree of credibility, namely the correlation coefficient. The degree of credibility, or degree of closeness, has been verified by the correlation coefficient. The higher the value (i.e., approaching 1), the greater the credibility and the better the choice for a suitable cluster model. The correlation coefficient was chosen on the basis of achieving a value approaching 1 via the farthest neighbor method. A prerequisite to performing the cluster analysis is that the data cannot be affected by multicollinearity.

Determining the relevant number of clusters began by using the clustering schedule, which determined a degree of distance of approximately $60 \%$. The relevant number of clusters was determined from below this level (Figure 7). The division of the countries into four clusters with the values of the individual indicators can be seen in Table 2 .

Figure 7 Dendrogram

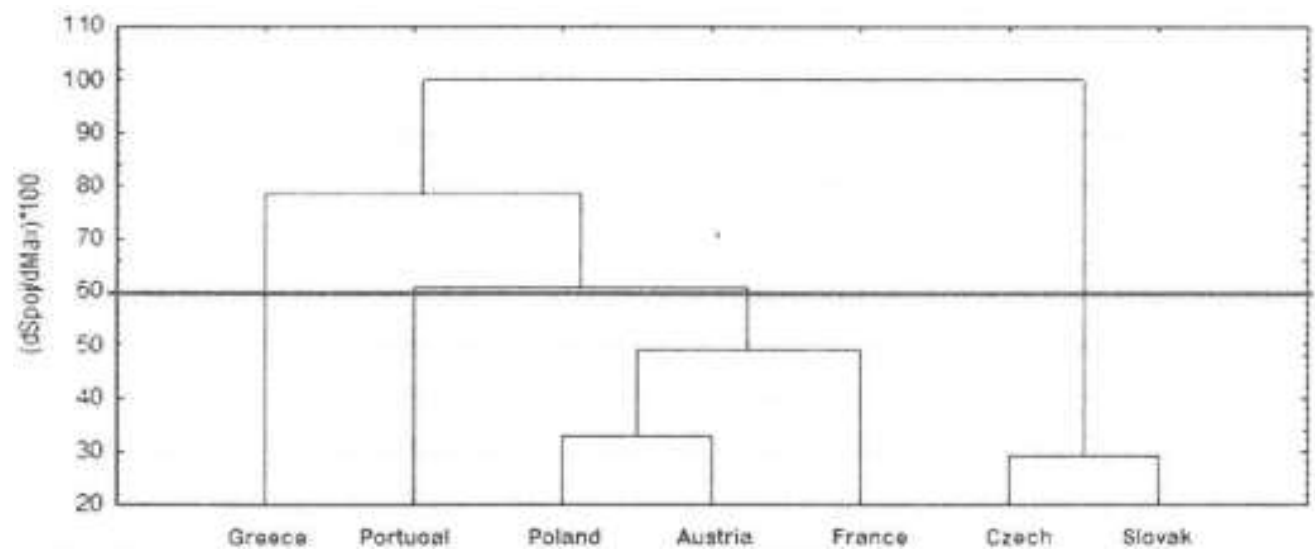

Source: Author's own work

Table 2 Average values of the selected indicators (in \%)

\begin{tabular}{clcccccc}
\hline Cluster & Country & $\begin{array}{c}\text { Change } \\
\text { in total } \\
\text { assets }\end{array}$ & $\begin{array}{c}\text { Liquid } \\
\text { ass./Total } \\
\text { assets }\end{array}$ & $\begin{array}{c}\text { Loans/ } \\
\text { Deposits }\end{array}$ & $\begin{array}{c}\text { Capit. } \\
\text { adeq. }\end{array}$ & ROA & ROE \\
\hline \hline \multirow{2}{*}{ 1st } & Slovakia & 1.4 & 36.2 & 110 & 17.93 & 1.3 & 9.1 \\
\cline { 2 - 8 } & Czech R. & 8.9 & 33.8 & 132 & 17.08 & 1.27 & 16.2 \\
\hline \multirow{2}{*}{ 2nd } & France & 9.6 & 39.1 & 81 & 15.03 & 0.5 & 8.4 \\
\cline { 2 - 8 } & Austria & -5.8 & 24.5 & 87 & 15.83 & 0.1 & 5.5 \\
\cline { 2 - 8 } 3rd & Poland & 4.0 & 21.4 & 90 & 14.91 & 1.1 & 14 \\
\hline 4th & Grtugal & -7.7 & 16.9 & 117 & 13.20 & -0.7 & -11 \\
\hline \multicolumn{2}{c}{$\begin{array}{c}\text { Average } \\
\text { total }\end{array}$} & -10.8 & 29.9 & 89 & 13.50 & 1.4 & -169 \\
\hline
\end{tabular}

Source: Author's own work acc. to Bankscope 


\section{Conslusions}

Four clusters were created using cluster analysis. Considering the efficiency of the banking sectors using the selected indicators with the first principal component, which explains almost $48 \%$ of the variability of the investigated group, the greatest correlations were the ratio of liquid assets to total assets and ROA. In the ratio of liquid assets to total assets, the best values were achieved by France, the Czech Republic, and Slovakia. The Czech Republic and Slovakia exceeded the average ROA limit without fail, but France did not. The average ROA value was also exceeded by Poland; however, it does not record results comparable to these countries in in its ratio of liquid assets/total assets. The first cluster is formed by the Czech Republic and Slovakia. Because France and Poland lag behind in at least one indicator, they are grouped into another cluster together with Austria. The third cluster consists of only one country, Portugal. Portugal achieved the worst results in both of the indicators listed above. The Greek banking sector achieved better results than Portugal, but because it achieved very low levels in the indicator corresponding to the second part of the component, it forms a separate cluster. It achieved high negative values especially in terms of ROE, which prevents it from being compared to other countries; therefore, Greece forms the fourth separate cluster.

Depending on the combination of the selected indicators, the cluster composed of the Czech Republic and Slovakia can be qualified as the cluster with the highest efficiency in the banking sector. This first cluster achieves significantly better values than the other banking sectors for the indicators examined here. These two banking sectors were not impacted by the global financial crisis (compared to Greece and Portugal and, to some extent, France). The average values of the indicators for the first cluster are significantly above the average for all markers in the selected banking sectors.

\section{Acknowledgments}

The paper has been created with the financial support of the Czech Science Foundation (project GACR No. 17-02509S, "Emerging financial risks during a global low interest rate environment").

\section{References}

Altunbas, Y. and Chakravarty, S. P. (1998). Efficiency measures and the banking structure in Europe. Economics Letters, 60(2), pp. 205-208.

Atemkeng, T. and Nzongang, J. (2006). Market structure and profitability performance in the banking industry of CFA Countries: the case of commercial banks in Cameroon. Journal of Sustainable Development in Africa, 8(2), pp. 114.

Abbasoglu, O. F., Aysan, A. F. and Günes, A. (2007). Concentration, competition, efficiency and profitability of the Turkish banking sector in the post-crises period. Banks and Bank Systems, 2(3), pp. 106.

Bankscope. (2014). World banking information source. Bureau van Dijk. 
Berger, A. N., Hancock, D. and Humphrey, D. B. (1993). Bank efficiency derived from the profit function. Journal of Banking \& Finance, 17(2), pp. 317347.

Bonin, J. P., Hasan, I. and Wachtel, P. (2005). Bank performance, efficiency and ownership in transition countries. Journal of Banking \& Finance, 29(1), pp. 31-53.

Černohorský, J. (2014). The Integration of Credit Markets. In Proceedings of 7th International Scientific Conference on Managing and Modelling of Financial Risks, Ostrava: VŠB-TU Ostrava, pp. 127-135.

Černohorský, J. and Prokop, V. (2016). The Relationship of Concentration and Profitability in Banking Markets. In Proceedings 15th International Conference on Finance and Banking, Karviná: Silesian University, pp.40-49.

Dabla-Norris, E. and Floerkemeier, H. (2007). Bank efficiency and market structure: what determines banking spreads in Armenia? IMF Working Papers, pp. 1-28.

Friedman, J., Hastie, T. and Tibshirani, R. (2001). The elements of statistical learning, 1st ed. Berlin: Springer series in statistics.

Fuentes, R. and Vergara, M. (2003). Explaining bank efficiency: bank size or ownership structure? In Proceedings of the VIII Meeting of the Research Network of Central Banks of the Americas, pp. 12-14.

Groeneveld, J. M. and de Vries, B. (2009). European co-operative banks: first lessons of the subprime crisis. The International Journal of Cooperative Management, 4(2), pp. 8-21.

Hedvičáková, M. and Svobodová, L. (2015). Analysis of Banking Fees and Clients' Needs. In Proceedings of the 12th International Scientific Conference on European Financial Systems 2015, Brno: Masaryk University, pp. 181-188.

Klímek, P. (2005). Data mining a jeho využití. E+M Ekonomie a Management, 8 (3), pp. $128-135$.

Mester, L. J. (1993). Efficiency in the savings and loan industry. Journal of Banking \& Finance, 17(2), pp. 267-286.

Molyneux, P. and Thornton, J. (1992). Determinants of European bank profitability: A note. Journal of Banking \& Finance, 16(6), pp. 1173-1178.

Polouček, S., et al. (2006). Bankovnictví. Praha: CH Beck.

Richard, P. J., Devinney, T. M., Yip, G. S. and Johnson, G. (2009). Measuring organizational performance: Towards methodological best practice. Journal of management, 35(3), pp. 718-804.

Romesburg, Ch. (2004). Cluster Analysis for Researchers. North Carolina: Lulu Press.

Stavárek, D. and Řepková, I. (2013). Efficiency in the Czech banking industry: A non-parametric approach. Acta Universitatis Agriculturae et Silviculturae Mendelianae Brunensis, 60(2), pp. 357-366.

Serdarevic, G. and Teplý, P. (2011). The Efficiency of EU Merger Control during the Period 1990-2008*. Finance a Uver, 61(3), pp. 252-276.

Svobodová, L. (2013). Trends in the number of bankruptcies in the Czech Republic. In Proceedings of International Conference, Hradec economics days 2013, Hradec Králové: Univerzita Hradec Králové, pp. 393-399. 
Tokarčíková, E., Ponisciakova, O. and Litvaj, I. (2014). Key Performance Indicators and their Exploitation in Decision-Making Process. In Proceedings of $18^{\text {th }}$ International Conference. Transport means 2014, Kaunas: Kaunas University of Technology, pp. 372-375.

Tulkens, H. (2006). On FDH efficiency analysis: some methodological issues and applications to retail banking, courts and urban transit. In Public goods, environmental externalities and fiscal competition, pp. 311-342.

Vodová, P. (2013). Liquid Assets in Banking: What Matters in the Visegrad Countries? E+M Eonomics and Management, 16(3), pp. 113-129.

Zou, H., Hastie, T. and Tibshirani, R. (2006). Sparse principal component analysis. In Journal of Computational and Graphical Statistics. 15(2), pp. 26528. 